\title{
A Framework for Plans Permeable Breakwater Eco-Friendly Building Identification and Characteristics Materials Construction Study Case at Demak Village
}

\author{
Denny Nugroho Sugianto ${ }^{1,2, *}$, Sugeng Widada ${ }^{1}$, Anindya Wirastriya $^{1,2}$, Aris Ismanto ${ }^{1,2}$, Retno Hartati ${ }^{4}$, Widianingsih ${ }^{4}$, Agus Indarjo $^{4}$, \\ Suripin 5 \\ ${ }^{1}$ Department of Oceanography, Diponegoro University, Semarang 50275, Indonesia.
}

${ }^{2}$ Center for Coastal Rehabilitation and Disaster Mitigation Studies, Semarang 50275, Indonesia.

${ }^{3}$ Doctorate Programme of Coastal Resources Management/Aquatic, Diponegoro University, Semarang 50275, Indonesia.

${ }^{4}$ Department of Marine Science, Diponegoro University, Semarang 50275, Indonesia.

${ }^{5}$ Department of Civil Engineering, Diponegoro University, Semarang 50275, Indonesia.

\begin{tabular}{l} 
A R T I C L E I N F O \\
\hline Article history: \\
Received: 27 September, 2019 \\
Accepted: 11 March, 2020 \\
Online: 20 March, 2020 \\
\hline Keywords: \\
Submerged breakwater \\
ocean wave \\
Jepara \\
coastal protection \\
mitigation
\end{tabular}

\begin{abstract}
A B S T R A C T
Demak is located on the north coast of Java, precisely in Central Java Province, Indonesia which has many problems related to erosion and shoreline degradation. This study attempts to analyze, identify, and select the materials to build eco-friendly permeable breakwater in Demak. The research was conducted during 2014, consist of several activities, i.e. identified the condition of breakwaters position, materials, and construction, did literature study of identification type breakwaters, study area, sediment, chemical reaction, then reverse design and modification for eco-friendly permeable breakwater. The result is a design of eco-friendly permeable breakwater which used a material of PVC pipe and Bamboo. PVC has excellent chemical resistance, also will increase sedimentation process and accelerate coastal changes towards the sea. Effectiveness level of breakwater made from combination of tire and PVC was 62\%, and reveal to be more economical than other general-purpose plastics such as PE, PP, or PS.
\end{abstract}

\section{Introduction}

Demak is located on the north coast of Java, exactly in Central Java Province, Indonesia that interesting to observed [1][2]. This area has many problems related to erosion and shoreline degradation [3]. Coastal abrasion in the north coast of Java is mainly influenced by ocean dynamics, like wave action, long shore current, and sea level rise also land susidance that caused erosion [4]. It would affect to shoreline line, and dangerous for community live in surrounding area.

Many attempts have been made to build breakwaters and plant mangrove to decrease abrasion. In 2014, Indonesian Ministry of Marine and Fisheries built breakwater using hybrid nature concept, this building can control hydrodynamics and deformation of wave energy. However, it was not effective to reduce wave energy, and sediment was not trapped inside perfectly [5][6]. Another problem was the evidence of wood

*Denny N. Sugianto, Email: dennysugianto.oceanography@gmail.com boring community which attack the bamboo pole used. Woodborers bore into wood not only for shelter but often also for nourishment [7]. This study attempts to analyse, identify, and plan the materials to build an eco-friendly permeable breakwater in Demak Coast.

\section{Literature Study}

\subsection{Study Area}

Indonesia is a maritime country which has 13,487 islands; 3'257'483 km² water area, and $95,181 \mathrm{~km}^{2}$ coastline [8]. Demak is one of the coastal areas, direct facing Java Sea. This research was conducted in Timbulsloko Village, Demak. This aims of research was to identify the condition of breakwaters position, materials, and construction.

Java Sea Wave has a uniqueness that is generated by the wind that is bounded by the islands of Java, Sumatra, Kalimantan and the Sulawesi Islands [8]. Demak has many problems related to 
erosion and shoreline changing [9]. The changing of coastal area is because the soil type of Demak is alluvial which is susceptible to coastal erosion process [2]. Provincial Development Planning Agency (Bappeda) reported that in 2007 Central Java Province faced coastal mangrove degradation, and the result of the study, in 2014 the ground cover vegetation of coastal mangrove was only $5.381,15$ ha [10].

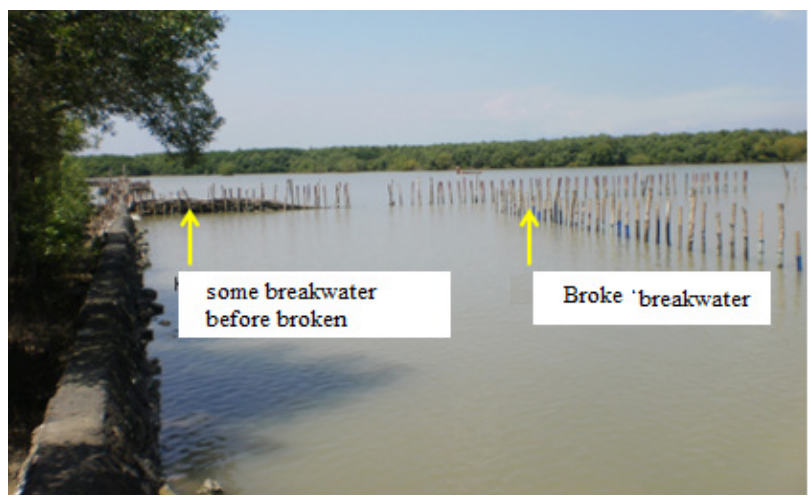

Figure 1: Submerged breakwater experiment layout.

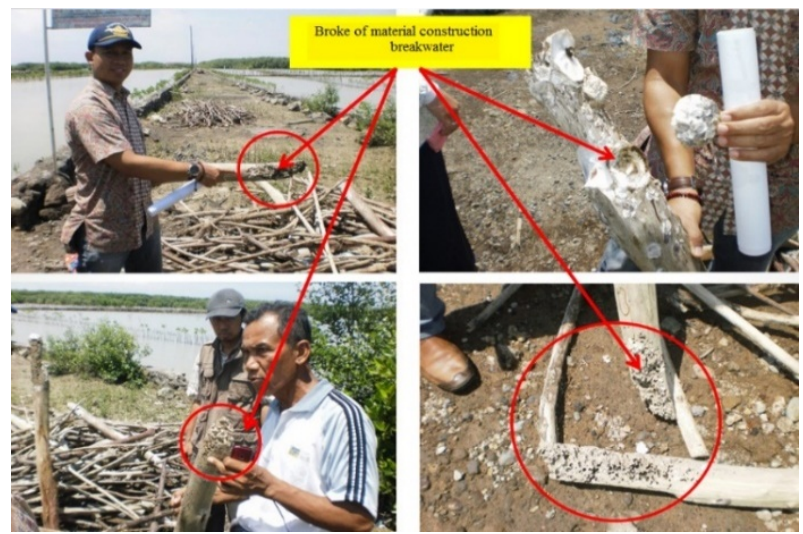

Figure 2: Problem face by materials of breakwaters (source : research study in 2014).

\subsection{Coastal Stucture Type}

Several types of coastal structure be important role to prevent coastal morpho-dynamycs. Proper layouts of coastal structures can lead to less intense sand transport near the beach [11]. Some types of coastal buildings are revetment, groin, jetty and reduce wave energy [12]. These buildings have several roles and functions. Revetment buildings are built on shorelines were used to protect beaches directly from wave attacks. Groins are building jutting from the beach into the sea used to capture or restrain movement of sediment along the coast, so the sediment transport along the coast is reduced. Groynes are protective structures, but, on the contrary, they may induce local strong flow around the head zone [12]. Jetty is a perpendicular building of coastline that is placed on both sides of the river mouth [11]. Setting of jetty construction can impact the longshore transport [13]. The third group is the breakwater (breakwater), which consists of 2 types, they are offshore and on-shore breakwaters [14] [15]. Waves break on these nearshore bars can reduce the level of wave energy [16]. Breakwaters protect shorelines from beach erosion and lessen the impacts on water quality and landscape [17]. Offshore www.astesj.com breakwater widely used as coastal protection against erosion by destroying the wave energy before it reaches the shore while the breakwater connecting the beach used to protect the waters of the port from wave disturbances, so that the ships can be docked [11] [18].

\subsection{Wave Breaker Stucture}

The main characteristic of a wave-permeable breakwater is that a wave can move through the breakwater without changing its profile, while wave diffraction is not dependent on whether the structure is permeable or not [19] [20] [21].Wave energy can induce sediment transport and shoreline changes [22] and also implication of breakwater orientation can be designed or altered to sediment transport in a desired direction [23]. Those sometimes constructed as countermeasures against beach erosion where the availability of sediments for nourishment is limited [24]. The construction of breakwater influenced by wave energy and sediment transport patterns of the study area [25].

The effectiveness of structure type to reduce wave energy is influenced by the geometric shape and configuration of the breakwater placement, as well as the water depth, height and wave period. The length of the breakwater and its distance from the shoreline determines the shoreline and sediment changes collected behind the breakwater structure concerned. There are some type of wave breaking structures as presented in Tabel 1 .

\subsection{Phytoplankton, Benthic Organism and Boring Community}

To get phytoplankton samples, researches used plankton net for phytoplankton with $100 \mu \mathrm{m}$ nets and $20 \mathrm{~cm}$ holes placed behind the boat and pulled with $10 \mathrm{~m}$ long nylon ropes for 10 minutes. The distance traveled is about $500 \mathrm{~m}$ and the volume of filtered seawater for each transport of plankton is $350 \mathrm{~m}^{3}$.

Then the sample is transported and taken to a laboratory where it is arranged in 5\% buffered formalin. Researchers use a hemocytometer under a compound microscope to count and identify phytoplankton cells. The van veen grab sampler is used to collect samples of benthos, the assemblage of organisms inhabiting the seafloor. The benthos in the sediment samples recovered after sieving through $0.5 \mathrm{~mm}$ mesh sieve and preserved with $10 \%$ formalin mixed with rose-bengale was brought to the laboratory in polythene bags.

Sediment with benthos were transferred to a large, whitebottomed tray, and the animals were hand sorted in laboratory. After this preliminary examination, the whole sample was treated with $70 \%$ alcohol and kept for further analysis.

Phyto-plankton in Demak coast were found consisted of two classes, i.e. Bacillariophyceae and Dinophyceae. Nine teen phytoplankton species $(80 \%)$ from Bacillariophyceae class were Amphipora, sp., Amphora, sp., Bacteriastrum sp., Biddulphia sp., Chaetoceros sp., Corethron sp., Coscinodiscus sp., Eucampia sp., Fragilaria sp., Leptocylindrus, sp., Melosira, sp., Navicula sp., Nitzschia sp., Pelagothrix sp., Pleurosigma sp., Rhizosolenia sp., Skeletonema sp., Thallassiotrix sp., Triceratium sp and dominated by Pleurosigma sp. Dinophyceae phytoplankton found in the study area were Peridium sp., Ceratium sp., Dinophysis sp. and Diploneis sp. 
Table 1: Some types of wave breaking structures and their disavantages and advantages.

\begin{tabular}{|c|c|c|c|}
\hline & Types & Disadvantages & Advantages \\
\hline 1. & $\begin{array}{l}\text { Type of box- } \\
\text { concrete (concrete } \\
\text { cube) }\end{array}$ & $\begin{array}{l}\text { - Requires a lot of large stone (rock weight more } \\
\text { than } 300 \mathrm{~kg} \text { per grain) in large quantities. } \\
\text { - Needs a strong foundation for the sludge. } \\
\text { Cheaper cost }\end{array}$ & $\begin{array}{l}\text { From the technical point of view is very } \\
\text { effective as wave energy damper. } \\
\text { Concrete cube have different gravity of } \\
\text { about } 2.4 \text { times of the water weight or } \\
\text { about } 2.4 \text { tons for } 1 \mathrm{~m}^{3} \text { of concrete. } \\
\text { - In terms of data execution, easy in } \\
\text { structuring. }\end{array}$ \\
\hline 2. & $\begin{array}{l}\text { Wooden Building } \\
\text { Type }\end{array}$ & $\begin{array}{l}\text { - The poles are not tight enough to withstand the } \\
\text { incoming waves. }\end{array}$ & $\begin{array}{l}\text { - Can reduce the rate of coastal erosion } \\
\text { and catch sediment in protected areas. }\end{array}$ \\
\hline 3. & $\begin{array}{l}\text { Tires combined } \\
\text { PVC }\end{array}$ & $\begin{array}{l}\text { - Will only be effective and work well for the } \\
\text { following coastal conditions: (1) wave height, } \\
\mathrm{H}<3.0 \mathrm{~m} \text { and wave period } \mathrm{T}=4-8 \text { seconds; } \\
\text { (2) current velocity } \mathrm{V}<0.5 \mathrm{~m} / \mathrm{s} \text {; (3) tidal } \\
\text { range }<1.1 \mathrm{~m} \text {; (4) coastal slope (slope) } 0,1 \% \\
<\tan \theta<0,5 \% \text {; (5) water depth }<2 \mathrm{~m} \text {; And a } \\
\text { sediment diameter of } 0.20 \mathrm{~mm}<\mathrm{D} 50<0.30 \\
\text { mm. } \\
\text { - PVC and tires have weaknesses because the } \\
\text { materials used more quickly brittle. }\end{array}$ & $\begin{array}{l}\text { Will encourage the sedimentation } \\
\text { process and accelerate coastal changes } \\
\text { towards the sea. } \\
\text { - Level of breakwatereffectiveness of } \\
\text { combined tire and PVC type is } 62 \% \text {. } \\
\text { - More economical }\end{array}$ \\
\hline 4. & Concrete Buis Type & - Less environmentally friendly & $\begin{array}{l}\text { - Concrete material is stronger, durable } \\
\text { and not easily damaged due to wind } \\
\text { conditions and waves that occur. } \\
\text { - Effectiveness level of Concrete Buis } \\
\text { type is } 85 \% \text {. }\end{array}$ \\
\hline 5. & $\begin{array}{l}\text { Bamboo Combined } \\
\text { Tires Type }\end{array}$ & - & $\begin{array}{l}\text { - Ease of self-help by community and non- } \\
\text { government organizations. } \\
\text { - } \text { Low cost. } \\
\text { - Ease in obtaining material. }\end{array}$ \\
\hline 6. & $\begin{array}{l}\text { Brushwood dam / } \\
\text { Permeable dam / } \\
\text { Hybrid engineering } \\
\text { type }\end{array}$ & - & $\begin{array}{l}\text { - Allows to capture maximum sediment } \\
\text { and minimize abrasion strength. } \\
\text { - } \text { Reduces wave energy and does not } \\
\text { reflect waves. } \\
\text { - Creating a calm water condition for mud } \\
\text { sediment. } \\
\text { - No need for cross section or grounding } \\
\text { as in breakwater combined bamboo tire } \\
\text { type. }\end{array}$ \\
\hline
\end{tabular}

The analysis shows that benthic organisms found in all study area mostly polycaheta $(95 \%)$ consist of $8-21$ species and $5 \%$ of bivalve and crustacean. Polychaetes have an important role in the function of benthic communities, in terms of recycling and reworking benthic sediments, bioturbation sediments and in the burial of organic matter. Polychaetes are abundant in most marine and estuary environments, both in terms of numbers of individuals and species. [26]. Polychaetes, by their burrowing and feeding activity, may considerably enhance various sedimentary processes. This benthic community take a great advantage from sedimentation as the impact of breakwater contruction.

The bamboo and wood materials used as material construction were found attacked by boring organism Barnea cf. candida (Figure 1) which is one of the most abundant and diversified of modern pholadid bivalves [27]. The colour of this boring bivalves were white, periostracum yellowish or light brown with inner surfaces white. Their shell were thin and brittle, elongate-oval, shaped rather like a date; anterior and posterior margins rounded, gaping posteriorly. Sculpture of corrugated concentric ridges and radiating lines, developed as sharp tubercles where they intersect, most pronounced anteriorly. They are filter-feeders and bore into inorganic and organic substrates of variable hardness and, occasionally, into waterlogged and decayed wood [27]. The diverse and abundance of phytoplankton in the study area provide excellent food the the bivalves so that Barnea cf. candida were found very dense $\left(15-21 \mathrm{indv} . / 10 \mathrm{~cm}^{2}\right)$ and caused the wood broken. The bamboo was also heavily attached by oysters (Crassostrea sp.) so the bamboo become weak and broken. Pholads such as Barnea sp. are particularly aggressive in tropical waters and causing extensive damage to wood[28]. 
Marine borers are wood boring invertebrates and other hard objects in the sea and brackish waters (as their habitat and foraging). Its nature that drills wood will cause damage to the wood structure and reduce the strength of the wood, and crustacean borers including multiple species commonly known as gribbles Goodell 2000 [29] [28]. Both shipworms and gribbles attack the wood piles for shelter and, at least in the case of shipworms, wood can also be digested through the aid of microbial symbionts [30] to supplement filter feeding nutrition.

\subsection{Phytoplankton, Benthic Organism and Boring Community}

Chemical reaction happen in breakwater inside materials construction which is sank in water. In study area a water has characteristics of salt water $\left(55 \% \mathrm{Cl}, 4 \% \mathrm{Mg}, 8 \% \mathrm{SO}_{4}, 31 \%\right.$ Natrium, Ca, etc), this shows good for phytoplankton growth.

There were several breakwater type such as tires-bambo combination (Figure 3), Bamboo and Concrete Buis Type (Figure $5)$. Waste tyres contain a carbon $(84,10 \%)$, oxygen $(10,36 \%)$, sulfur $(0,48 \%)$, silicon $(0,07 \%)$, and $\mathrm{Zn}(5,04 \%)$. Carbon inside in waste tyres will produce more $\mathrm{CO}_{2}$ and it will make acid condition in aquatic :

$$
\begin{gathered}
2 \mathrm{NaCl}+\mathrm{CO}_{2}+\mathrm{H}_{2} \mathrm{O} \rightarrow 2 \mathrm{HCl}+\mathrm{Na}_{2} \mathrm{CO}_{3} \\
\text { Salt }+ \text { Carbon dioxide }+ \text { Water } \rightarrow \text { Acid }+ \text { Metal Cabonates }
\end{gathered}
$$

In the location where the Concrete Buis Type was used as breakwater, it showed more effective as wave energy reducer. Concrete materials have 2.4 times of the water weight or about 2.4 tons for $1 \mathrm{~m}^{3}$ of concrete. Concrete material is stronger, durable and not easily damaged by wind and waves [31][4]. However this type is less-environmental-friendly because produce heavy metals such as $\mathrm{Pb}, \mathrm{Ag}$, and $\mathrm{Cr}$.

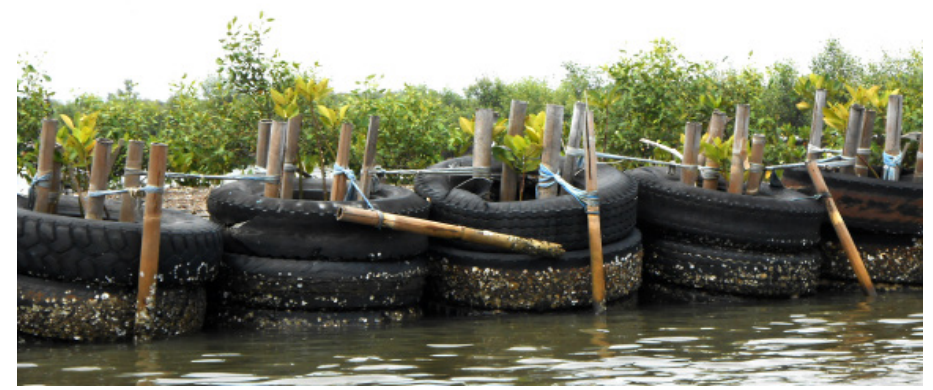

Figure 3: Breakwater of tires bambo combination type in study area.

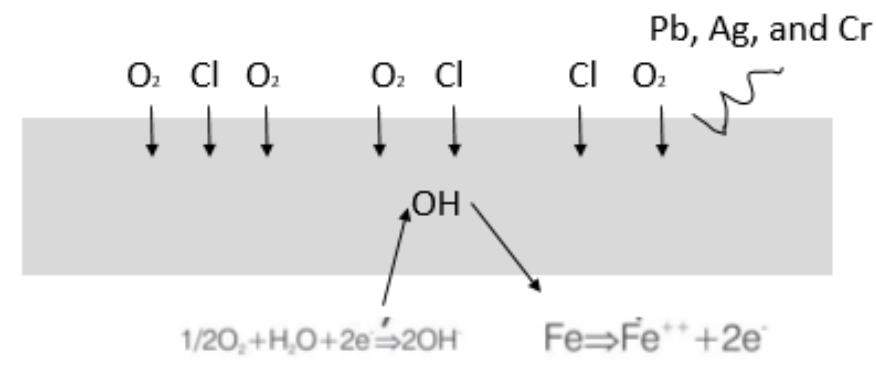

Figure 4 Chemical reaction inside concrete buis type.

10 elements were selected: barium, strontium, cadmium, chromium, cobalt, copper, manganese, nickel, vanadium, and mercury for further investigation. Some of these metals, $\mathrm{Cd}, \mathrm{Cr}$, $\mathrm{Ni}$ and $\mathrm{Hg}$, are known as poisons or are suspected carcinogens. Metal air emissions are the biggest concern because of the health risks resulting from this release. Several studies in cement have tried to study the fate and distribution of metals found in waste fuels. The amount of mercury transferred to the clinker or cement is difficult to determine because of the high volatility.

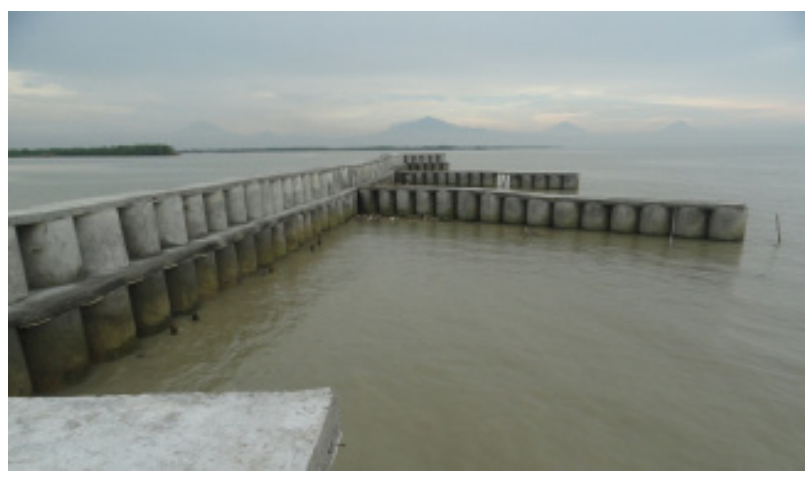

Figure 5: Breakwater of concrete buis type built on 2012.

\subsection{Phytoplankton, Benthic Organism and Boring Community}

Indonesia has two characteristics season depend on the rainfall. There are four condition regularly happened which were known as northwest-northeast monsoon, first transitional season, southeast-southwest monsoon and the second transitional season. The differences of wave length and wave height are influenced by seasonal variation. Characteristics of waves study is very important because it deal with the strength of wave.

Research report by Ismanto et al [9] stated that the sediment concentration distribution model results in Figure 3. Seen from tides scenario that the highest flood tide (Figure 6a) change the concentration of sediment dominant with a distance of $6 \mathrm{~km}$ from the source of pollutants where sediment concentration values ranging between $0,015-0,045 \mathrm{~kg} / \mathrm{m}^{3}$. While the condition of the lowest tide ebb sediment concentrations scattered small enough dominance in which the value of sediment concentration ranges beetween $0,01-0,03 \mathrm{~kg} / \mathrm{m}^{3}$ with a distance of $3 \mathrm{~km}$ distribution (Figure 6b). This sediment transport patterns affected by the tidal patterns, where the pattern of sediment transport and the direction of ocean currents towards to near the shore in accordance with the conditions of simulated at high tide. According to Gyr and Hoyer [11] sediment transport patterns are not only influenced by the mass of water flow patterns but also depend on monsoon different wind conditions. The simulation shows that the distribution of sediment is quite small because of the small ocean currents velocity.

\section{Result and Conclusion}

This study found several factors affected the breakwater effectiveness in Demak coastline, so there is urgent need to select construction materials for breakwaters which are economic, high durability, and eco- friendly. Basically, ecosystem rehabilitation activities is an attempt to restore the degraded ecosystem. This integrated approach is called eco-friendly permeable breakwater, i.e. brushwood dam breakwater type. Based on the characteristics area, there are several materials which may be chosen to construct the breakwater as given in Table 1 . 


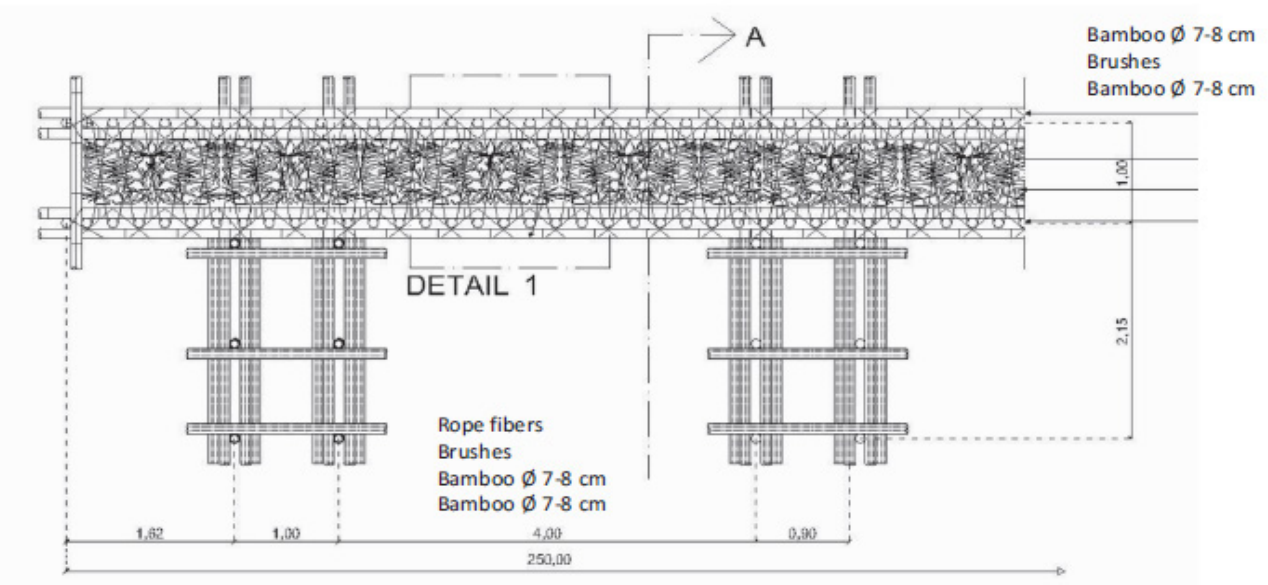

(a)
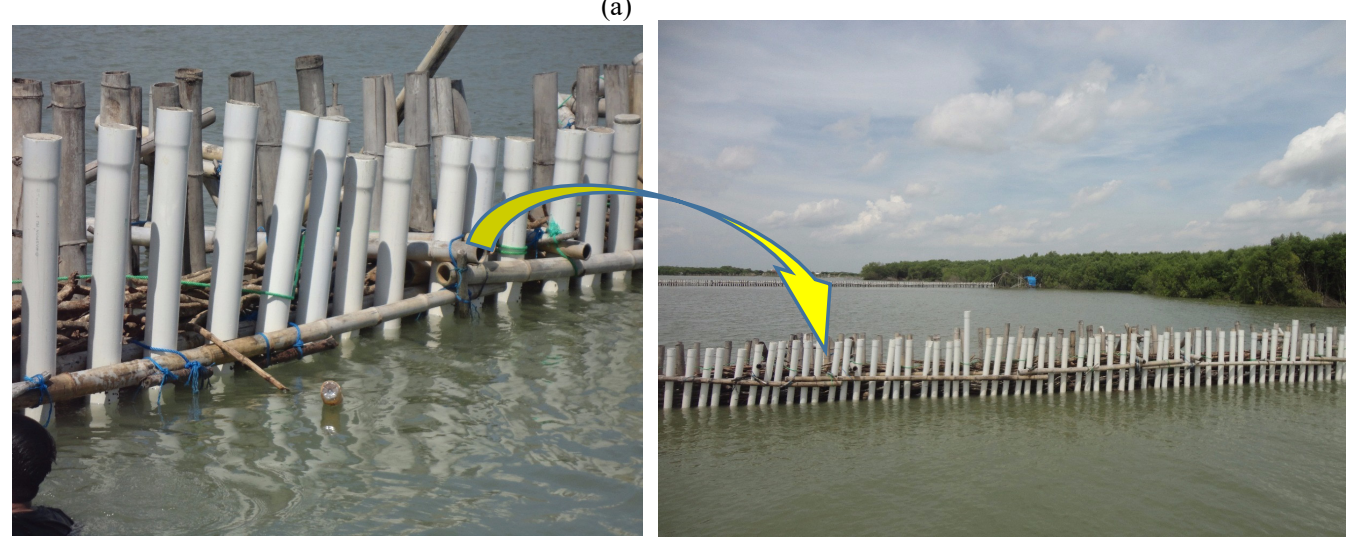

(b)

Figure 6: (a) Design of eco-friendly hybrid permeable breakwater

Table 2 : Economic analysis of construction materials.

\begin{tabular}{lclc}
\hline \multicolumn{1}{c}{ Materials } & Durability & \multicolumn{1}{c}{ Treatment } & Cost (USD)/meter \\
\hline PVC & $4-5$ years & $\begin{array}{l}\text { Interfenced by human (almost } \\
\text { no) }\end{array}$ & $90-100$ \\
Bamboo & $3-4$ years & $\begin{array}{l}\text { Attacked by boring community } \\
\text { (slower) }\end{array}$ & $80-90$ \\
Wood & 8 month -2 years & $\begin{array}{l}\text { Attacked by boring community } \\
\text { (faster, more quickly damage) }\end{array}$ & $60-75$ \\
$\begin{array}{l}\text { Pipe Concrete } \\
(\varnothing 90 \mathrm{~cm})\end{array}$ & $7-10$ years & $\begin{array}{l}\text { Heavy weight, landslide by } \\
\text { sediment, chemical reaction }\end{array}$ & $250-350$ \\
\hline
\end{tabular}

The construction of this type of breakwater restore the habitats for mangroves replant which require surface sedimentation, the greater sedimentation rates the faster mangrove growth. The sedimentation rate is in the proportion with sediment concentration in the water column, in which could be increased by dredging agitation and restoration motion. Massive structures (pipe concrete) were too expensive. The bamboo and PVC combination type permeable breakwater would naturally provides a variety of ecosystem needs, such as coastal protection (adjustable according to sea level rise), fishery resources, as a nursery of marine biota, and improve water quality.

\section{Conclusion}

Based on the analysis among factors caused breakwater damage's in study area of Timbul Sloko village of Demak regency is chemical reaction, characteristics sediment, and crustacean borers. Eco-friendly permeable breakwater type aims to restore mud beaches for mangroves replant by restoring lost areas due to erosion and abrasion.

The best materials recomend for eco-friendly permeable breakwater are the bamboo and PVC combination. PVC has excellent chemical resistance, cause increase of sedimentation process and accelerate coastal changes towards the sea. Effectiveness level the bamboo and PVC combination breakwater type is $62 \%$, and more economical than other general-purpose plastics such as PE, PP, or PS.

\section{Conflict of Interest}

The authors declare that there is no conflict of interest regarding 
the publication of this paper.

\section{Funding Statement}

The work was funded by Ministry of Research Technology and Higher Education (Ristek Dikti) Republic of Indonesia, with grant number 257-104/UN7.P4.3/PP/2019.

\section{Acknowledgment}

We would like to thank to Oceanography Department Diponegoro University, Center for Coastal Rehabilitation and Disaster Mitigation Studies (CoRem-PKMBRP) - Center of Excellence Science and Technology (PUI), LPPM Diponegoro University and Ministry of Research Technology and Higher Education (Ristek Dikti) Republic of Indonesia for funding our research.

\section{References}

[1] M.A. Marfai, "The hazards of coastal erosion in Central Java, Indonesia: An overview," Malaysia Journal of Society and Space, vol. 7, no. 3, pp. 1 - 9, 2011.

[2] Badan Pusat Statistik," Kecamatan dalam angka di Demak," 2012.

[3] S. Bagli and P. Soille," Morhological automatic extraction of Pan-European coastline from Landsat ETM+images," International Symposium on GIS and Computer Cartography for Coastal Zone Management, October, Genova, 2012.

[4] Suripin, D.N. Sugianto and M. Helmi," Mangrove restoration with environment friendly permeable breakwater," Asian Journal Biotech Envioremental, vol. 19, no. 1, 2016.

[5] P. Hawati, D. N. Sugianto, S. Anggoro, et al., "Waves induce sediment transport at coastal region of Timbulsloko Demak," IOP Conf. Series: Earth and Environmental Science, vol. 55, Article ID 012048, 2017.

[6] I. Alifdini, Y.O. Andrawina, D.N. Sugianto, et al., "Technology application of oscillating water column on the Sungai Suci Beach as solutions for make a renewable energy in Coastal Bengkulu, Indonesia," 3rd Asian Wave and Tidal Energy Conference (AWTEC) Proceeding, vol. 2, Nanyang Technological University, Singapore, 2016.

[7] I.M.S. Borges, A.A. Valente, P. Palma, et al., "Changes in the wood boring community in the Tagus Estuary: a case study," Marine Biodiversity Records, vol. 3, pp. 1-7, 2010.

[8] D.N. Sugianto, M. Zainuri, A. Darari, et al., "Wave height forecasting using measurement wind speed distribution equation in Java Sea, Indonesia," International Journal of Civil Engineering and Technology, vol. 8, no. 5, pp. 604-619, 2017.

[9] A. Ismanto, M. Zainuri, S. Hutabarat, et al., "Sediment transport model in Sayung District, Demak," IOP Conf. Series: Earth and Environmental Science, vol. 55, Article ID 012007, 2017.

[10] J. Gu, Y. Ma, B. Wang, et al., "Influence of near-shore marine structures in a beach nourishment project on tidal currents in Haitan Bay, facing the Taiwan Strait," Journal of Hydrodynamics, vol. 28, no. 4, pp. 690-701, 2016.

[11] B. Triatmodjo, "Teknik Pantai (Coastal Engineering)," Beta Offset, Yogyakarta, 1999.

[12] A. Safarzadeh, A. H. Zaji and H. Bonakdari, "Comparative assessment of the hybrid genetic algorithm-artificial neural network and genetic programming methods for the prediction of longitudinal velocity field around a single straight groyne," Applied Soft Computing, vol. 60, pp. 213-228, 2017.

[13] E. Garel, C. Sousa and O. Ferreira, "Sand bypass and updrift beach evolution after jetty construction at an ebb-tidal delta," Estuarine, Coastal and Shelf Science, vol. 167 (A), pp. 4-13, 2015.

[14] J. Shen, H. Wu and Y. Zhang, "Subsidence estimation of breakwater built on loosely deposited sandy seabed foundation: Elastic model or elasto-plastic model," International Journal of Naval Architecture and Ocean Engineering, vol. 9, no. 4, pp. 418-428, 2017.

[15] H.D. Soo, W.C. Cho, J. S. Yoon, et al., "Applicability of multiple submerged narrow-crested breakwaters for reduction of mean water level in rear side and flow control," Journal of Coastal Research: Special Issue, vol. 79, pp. 179-183, 2017.

[16] B. Grasmeijer, "Process-based cross-shore modelling of barred beaches,"

www.astesj.com
Nederlandse Geografische Studies, vol. 302, pp. $19-251,2002$.

[17] D.S. Hur, W.D. Lee and W.C. Cho, "Characteristics of wave run-up height on a sandy beach behind dual-submerged breakwaters," Ocean Engineering, vol. 45, pp. 38-55, 2012.

[18] S. Baker, N. Sultan, A. Cornett, et al., "Physical modelling and design optimizations for a new port in brazil. coastal structures and solutions to coastal disasters, 2015: resilient coastal communities, " Proceedings of the Coastal Structures and Solutions to Coastal Disasters Joint Conference, pp. 838-847, 2015.

[19] I. Aouiche, L. Daoudi, E.J. Anthony, et al., "Alongshore variations in morphology and incident wave energy on a human-impacted coast: Agadir, Morocco," Journal of Coastal Research, vol. 1, no. 75, pp. 1027-1031, 2016.

[20] I. Alifdini, D.N. Sugianto, Y.O. Andrawina, et al., "Identification of wave energy potential with floating oscillating water column technology in Pulau Baai Beach, Bengkulu," IOP Conf. Series: Earth and Environmental Science, vol. 55, Article ID 012040, 2017.

[21] D. Dykstra, X. Xing, and C. Devick, "Floating breakwater modeling and design for oyster point marina," Coastal engineering practice," Proceedings of the 2011 Conference on Coastal Engineering Practice, pp. 903-916, 2011.

[22] V. Noujas, K.V. Thomas, L. S. Nair, et al., "Management of shoreline morphological changes consequent to breakwater construction," Indian Journal of Marine Sciences, vol. 43, no. 1, pp. 54-61, 2014.

[23] N.L. Jackson, M.D. Harley, C. Armaroli, et al., "Beach morphologies induced by breakwaters with different orientations," Geomorphology, vol. 239, pp. 48-57, 2015.

[24] Y. Kuriyama and M. Banno, "Shoreline change caused by the increase in wave transmission over a submerged breakwater due to sea level rise and land subsidence," Coastal Engineering, vol. 112, pp. 9-16, 2016.

[25] L. Benedet, J.P.F. Dobrochinski, D.J.R. Walstra, et al.,"A morphological modeling study to compare different methods of wave climate schematization and evaluate strategies to reduce erosion losses from a beach nourishment project," Coastal Engineering, vol. 112, pp. 69-86, 2016.

[26] P. Hutchings, "Biodiversity and functioning of polychaetes in benthic sediments," Biodiversity and Conservation, vol. 7, pp. 1133-1145, 1998.

[27] S. Monari, "Phylogeny and biogeography of pholadid bivalve Barnea (Anchomasa) with considerations on the phylogeny of Pholadoidea," Acta Palaeontologica Polonica, vol. 54, no. 2, pp. 315-335, 2009.

[28] R. Lopez-Anido, A.P. Michael, B. Goodell, et al., "Assessment of Wood Pile Deterioration due to Marine Organisms," J. of Waterway, Port, Costal and Ocean Engineering, vol. 130, no. 2, pp. 70-77, 2004.

[29] B. Goodell, "Wood products: deterioration by insects and marine organisms," Encyclopedia of materials science and technology, Elsevier, New York, 2000.

[30] E.A. Lawry and C.S. L. Arrowsmith, "Monitoring of geotextile offshore breakwaters to enhance mangrove re-vegetation," Australian Coasts and Ports, pp. 497-501, 2015.

[31] A.F. Zakki, D.M. Bae, S. Susilo, et al., "Structure design and characteristic analysis of buckling strength on swedge frame pressure hull with finite element analysis," ARPN Journal of Engineering and Applied Sciences, vol. 12, no. 3, pp. 821-833, 2017. 